\title{
THE HISTORY OF MANAGEMENT ACCOUNTING IN FRANCE, ITALY, PORTUGAL, AND SPAIN
}

\section{IE Working Paper $\quad$ WP05-30 18-11-2005}

Salvador Carmona

\author{
Instituto de Empresa Business School \\ Calle María de Molina, 12-5 \\ 28006 Madrid (Spain) \\ E-mail: salvador.carmona@ie.edu
}

\begin{abstract}
Historical research has shown the influence of environmental contexts on the design and functioning of management accounting systems. In contrast to the relatively competitive settings that witnessed the emergence of cost systems in Anglo-American contexts, the focal settings featured inter alia the imposing role of religious and social philosophers' ideas on society as well as distinctive degrees of state intervention in the economy. The findings question traditional contentions that double-entry bookkeeping spread from the fifteenth through the eighteenth centuries and that cost calculations have been implemented only since the advent of the British Industrial Revolution.
\end{abstract}

\section{Keywords}

Management Accounting Systems, Competition, Regulation, Monopoly, History. 



\section{Introduction}

Recent historical research has illuminated the miscellany of organizational and social variables that mediated the emergence of early cost calculations (Zan, 2004a). In particular, such research has added to the already vast number of studies of the relatively competitive textile and iron industries in Anglo-Saxon settings (e.g., Edwards and Boyns, 1992; Fleischman and Parker, 1997; Tyson, 1998).But also, increasing numbers of investigations have addressed the emergence of cost accounting in environments where markets and competition were less important--for example, Spain and its overseas colonies during the sixteenth to nineteenth centuries. These studies have justified Scott's (1995: 146) assertion: "It is difficult, if not impossible, to discern the effects of institutions on social structures and behaviors if all our cases are embedded in the same or very similar contexts".

In this chapter I review research that has examined early practices of cost accounting, ${ }^{1}$ as well as early theorizing about cost, in Latin settings in present-day France, Italy, Portugal, and Spain. Such a review is of interest for at least two reasons. First, the four focal countries witnessed varying degrees of state intervention in the economy and of market competition, which in turn influenced specific practices of cost management (Nikitin, 1990; Gutiérrez Hidalgo and Romero Fúnez, 2001a, b).. Second, a number of investigations have focused specifically on the two-way causal connections between cost accounting systems and organizational reforms (Núñez Torrado, 2002a; Alvarez-Dardet et al., 2002). In sum, the wider social, political, and economic contexts in our four focal countries exerted a considerable influence on the design and functioning of early cost accounting systems, and this review illustrates how such systems reflected social change (Bhimani, 1994a: 400).

Accounting history research published in international journals focuses overwhelmingly on the narrow time segment 1850-1940 (Carmona, 2004). Accounting historians working on our focal countries, on the other hand, have covered a much longer period of time. As Zan (2004b) argues, new research on cost accounting practices in proto-industrial settings is questioning the traditional assumption in accounting historiography that although the sixteenth and seventeenth centuries saw the spread of double-entry bookkeeping, costing and other managerial uses of accounting emerged only from the end of the eighteenth century. Accordingly, the observation period of this review extends from the sixteenth century through to the Second World War.

\section{Management Accounting Historiography in the Focal Countries}

The historiography of management accounting differs across the countries addressed in this review. In the case of France, Boyns et al. (1997a: 9) noted that "it is only in recent years that the development of accounting in that country has become a focus of study". However, growing interest has resulted in relevant findings that have been published in well-regarded journals, both in France and internationally. In general,

\footnotetext{
${ }^{1}$ Present-day understandings of management accounting in firms can hardly be applied to emerging practices, such as those performed by organizations in proto-industrial settings. The latter usually lacked the scope, frequency, purpose, and encompassing features that characterize management accounting systems in today's firms. Therefore, I use the term "cost calculations" to refer to such early practices.
} 
French accounting historians like Lemarchand (1993, 1994, 2002), Nikitin (1990), and Berland (1998a, 2001) have focused on practices spanning the eighteenth to the twentieth centuries and on the contributions of authorities who influenced the deployment of cost accounting practices in organizations. Lemarchand and Nikitin (2000) maintain that France played an important role in disseminating accounting practices and theoretical ideas across European countries. This topic has attracted international interest, from the early study of Garner (1954, Chapter 2) concerning the work of nineteenth-century French authors on the notion of cost and cost calculations to more recent work by academics from outside our focal countries (e.g., Bhimani, 1993, 1994a b), and has generated fruitful cooperation between French and British scholars (Lemarchand and Parker, 1996; Boyns et al., 1996, 1997a b; Berland and Boyns, 2002).

Italian accounting scholars have traditionally shown interest in historical research (Carmona, 2004). However, as Zan (1994) notes, this interest has been split between early accounting practices and later theories. On the one hand, there is what Zan (1994: 258) calls "a considerable body of research investigating ... accounting practice in the thirteenth and fifteenth centuries, concentrating on the emergence of the 'Italian method' of double-entry bookkeeping" (e.g., Bisaschi, 2003; Riccaboni et al., 2006). But such interest in the practice of accounting disappears for the centuries after the publication of Paciolo's Summa. According to Zan, research in Italian accounting history since the end of the fifteenth century has focused largely on the history of accounting thought. This bifurcated research pattern explains the contention of Antonelli et al. (2005) that "outside of the activities of the state-run Venice Arsenale in the seventeenth century ... few published works have examined costing activities in Italian industrial enterprises since the seventeenth century" (see also Bergamin Barbato et al., 1996). Consequently, Italian investigations into the history of management accounting have been relatively sparse until quite recently (e.g., Antonelli et al., 2002, 2005; Cinquini and Marelli, 2002).

Portuguese accounting scholars have demonstrated interest in the history of the discipline, focusing primarily on events and biographies of the twentieth century (Silva de Serra Faria, 2005), and on the role of various educational institutions in the emergence of the accounting profession in Portugal (Rodrigues and Craig, 2004; Rodrigues et al., 2003, 2004). To a lesser degree, these research efforts have addressed management accounting issues.

In Spain, following the lead of Esteban Hernández-Esteve, accounting historians traditionally focused on issues related to the implementation of double-entry bookkeeping in the public and private sectors and on treatises addressing accounting issues. Until the late 1980s, there was little interest in an historical examination of cost accounting practices. However, this situation changed with Gutierrez Hidalgo's research on cost and spatial practices at the Royal Tobacco Factory of Seville (RTF) during the eighteenth century (Gutiérrez Hidalgo, 1993). Since the 1990s, many accounting scholars have followed suit, especially by examining cost calculations in royal factories during the eighteenth and nineteenth centuries (Gutiérrez et al., 2005).

In the next section I review some examples of cost calculations deployed during the Renaissance, as well as the interplay between such practices and the Scholastics' views on the organization of the economy. Similarly, I embed the examination of cost accounting practices before the Industrial Revolution in their wider contexts, especially in the ideas of mercantilists. The section on the nineteenth century examines both cost 
accounting thought and practices, the latter illustrating the emergence of industrial accounting in France, Italy, and Spain. I then analyze the intertwining of scientific management ideas and cost accounting practice that occurred in France and that paved the way for practices of budgetary control. The chapter ends with an analysis of the main findings and some suggestions for further research in this area.

\section{Cost and Management Accounting Practices in the Renaissance}

\section{$\underline{\text { Scholasticism and Economic Issues }}$}

Medieval Catholic discourse included rules and guidelines regarding commerce, trade, prices, profit, and usury. The Scholastics, for example, developed a theory of economic systems in which the most difficult cases of conscience were to be decided by appealing to the Bible and the doctrine of Aristotle..$^{2}$ To speculate was to "sin most gravely" (De Roover, 1967). Drawing on the moral philosophy of Aristotle, the Scholastics stated that traders should charge a "just price" (Wren, 2000), as an antidote to avarice and gluttony. However, as de Roover (1967) notes, there was no general agreement on the nature of a "just price": for some it was the amount that allowed people to maintain their social status; to others it was the cost of production; for yet others it could be set at a maximum or minimum level by legal authorities.

The notion of just price was linked to the idea of profit. St. Thomas Aquinas (1273) reasoned that the exchange of property, as by a tradesman whose business is the trading of commodities or money, is both natural and necessary when it is done in order to satisfy the needs of life. In contrast, the exchange of commodities or money, "not on account of the necessities of life, but for profit ... is justly deserving of blame ... it satisfies the greed for gain which knows no limit and tends to infinity". Profit, in and of itself, is not sinful. It becomes lawful if intended to maintain one's household, to assist the needy, or to fill a clear and present need of one's country. In such cases, it is not an end in itself to seek gain. It is "payment for a person's labour".

The notion of competition was wholly neglected in the writings of Scholastics until the end of the sixteenth century (Wren, 2000); instead, attention was paid to the role of the state in price setting. Aquinas pointed out, "those who govern the state must determine the just measure of things saleable ... it is not lawful to disregard such measures as are established by public authority or custom" (Aquinas, 1273: 320 and 323, emphasis added). A higher price, however, could be asked if the seller "has changed something for the better ... or because the value has changed with the change of place or time ... [or] on account of the danger incurred in bringing the object to the market" (Ibid., 328).

In this chapter, I assume that the ideology of the Catholic Church exerted a distinctive influence on understandings of the economy and societal movements during the ancien régime and, hence, on the notions of cost and profit. But this assumption does not necessarily imply that such understandings were peculiar to the four countries examined in this chapter. Quattrone (2004: 651) contends that the differences between Lutherans and Catholics were not great.

\footnotetext{
2 This review of Scholasticism and the economy is based on Carmona and Macintosh (2002).
} 


\section{$\underline{\text { Cost calculations in regulated markets }}$}

Scholastic doctrine on the functioning of the economy provided a rationale for Catholic states to enforce mechanisms to deter overpricing as well as ensure the supply of basic goods to the public (Lane, 1944; Yamey, 2000). These ideas also interacted with environmental events such as plagues to lead some European kings to regulate markets (Fernández Conde, 2004). The Royal Soap Factory of Seville (RAS) exemplifies a firm operating in a regulated market (Carmona and Donoso, 1999, 2004; for the printing industry, see Martínez Guillén, 2005). On 23 May 1396, King Enrique II of Castile granted the monopoly of soap production and distribution in the City of Seville to Archbishop Ruy López-Dávalos. In 1423, King Juan II expanded the privilege to the entire area of influence of Seville and granted it to Admiral Alonso Enriquez, who simultaneously received the Dukedom of Alcalá. Importantly, the granting decree established that the price of soap should be set by the local government of Seville. Naturally, the Duke of Alcalá and the local government engaged in continuous disagreements over the just price of soap. Such disputes were resolved by ad hoc tests that reproduced the soap production process with the intention of calculating the production cost of a pound of soap. These tests required detailed standard procedures to guarantee objectivity, as well as sophisticated cost calculations.

Archival evidence demonstrates that tests were conducted as early as 1520 and constituted a regular practice during the sixteenth and seventeenth centuries, leading Carmona and Donoso (2004: 149) to suggest that such tests constituted an "institution" in the sense defined by Meyer and Rowan (1977). The 1525 test, the first in the archives, was developed at the initiative of the local government of Seville, which considered the soap price "too high". Two soap experts from outside the City of Seville were hired to conduct the test; to preserve their independence and to buffer them from pressures, they were not allowed to stay overnight in the city during the testing period. A local judge supervised the tests, and a Church accountant kept the records and wrote the final report, demonstrating the existence of accounting expertise among the clergy, as well as their involvement in economic developments (see also Quattrone, 2004). The tests usually began on Saturdays and the cauldron containing the soap was sealed until Monday, by which time the soap had solidified and was weighed.

Cost calculations accounted for the raw materials used in the soap production process: olive oil, ashes, lime, wood, and lye. Representatives of the local government and the duke, along with the Church's accounting expert, estimated the factory's annual cost, which involved such items as maintenance, taxes, fabrication of sundry materials, the loss of the rent that would have been obtained if the building hosting the RAS had been leased to another user, and the salary of the administrator. The factory costs were allocated to the expected annual production of soap in order to calculate the cost per pound of soap. Because no allowance for profit was formally acceptable at the time, this cost was also expected to become the market price. For the test conducted in 1525 , difficulties in dealing with decimals left a remainder of 14,500 maravedies of the factory's annual costs that could not be allocated to the cost per pound of soap, and the decision was not to increase the soap price correspondingly but to swallow the incalculable costs in order "to benefit the people of Seville".

Cost calculations performed at the RAS have some additional implications. For one thing, the case of the RAS shows considerable sophistication in cost calculations. 
To use present-day terminology, the authorities involved not only were aware of such notions as standards of performance of raw materials, labour, and capacity, but also incorporated more sophisticated ideas like opportunity cost (e.g., the rent that would have been obtained if the building in which the factory was located had been leased to another user). Furthermore, as Graves and Radcliffe (2004: 82) note in their comments on this investigation, the local government and the duke prepared costing schemes to bolster their respective cases. For example, the duke's representatives argued that the tests should include the salary of a priest in the cost of a pound of soap, because religious services had to be offered to operators on Sundays. In general, the ascribed objectivity of costing calculations created a rhetoric that could support the interests of both conflicting parties. The length of the observation period of this study provides a perspective on the changing role of the notion of private profits and the way in which costing calculations supported a case for profit (Carmona and Donoso, 1999). Although it was not possible in 1525 for the representatives of the duke to claim profits on an activity that was intended to deliver a public service, in implicit accord with the dictates of the Scholastics, this understanding of profit changed around 1692, near the end of the observation period. During the negotiations that followed the test conducted that year, the duke challenged the attempt of the local government representatives to include an additional 8 percent cost for deterioration of the materials and the stored soap, as "if such expense is considered, then there will be no allowance for earnings. This lacks support [because] what is expense is not earnings, and earnings cannot be denied to the purveyor. Moreover, the privilege will be useless if I cannot profit from it" (Carmona and Donoso, 2004: 147-148).

\section{Cost and management discourses in state-owned monopolies}

During the Renaissance, state-owned monopolies operated for strategic or fiscal reasons. The case of the Venice Arsenal illustrates the former: the Venetian Republic relied on the Arsenal to guarantee the Republic's security at sea and to preserve its trading and wealth. The Arsenal, termed by Galileo "the factory of wonders", mobilized a complex work organization that could assemble a galley in a few hours. And it produced records that cover sixty-five kilometres of shelving in the Venetian State Archive.

Accounting and management scholars investigating this archive have focused thus far on the management and accounting discourses that emerged in that setting between 1580 and 1679 (Zan 2004b; Zambon and Zan, 2005). These discourses began with the aftermath of the 1570 Battle of Lepanto against the Turkish fleet, which resulted in the Republic's decision, in 1580, to keep a reserve of 100 light galleys plus 12 great ones; and they ended on the eve of the 1679 Candia crisis, which signalled the decay of Venice's sovereignty over the eastern sea.

Archival evidence suggests that the Arsenal enforced new forms of management through accounting, techniques that in present-day terminology would be referred to as organizational design and the logic of the budget (Zan, 2004b: 146). Furthermore, accounting and managerial discourses evolved over the period studied, consistently incorporating innovative operational concepts such as work-in-progress. In general, Zan argues that such forms of economic discourse emerged in a context of societal norms that were particularly hostile as a consequence of the working traditions imposed by the work gangs. The ethos and pathos of concepts like efficiency, apparent in the archival 
material, would have further implications for subsequent re-examinations of the "genesis" of management.

Zan (2004b) examined both regularity and change in the managerial and accounting discourses at the Arsenal. Discursive regularities included issues and problems addressed in the reports issued by elective officers, such as ship inventories, ship deterioration, and the the number of ships required to be at different stages of completion in order to keep 100 galleys in reserve. As Lane (1934:242) notes, this goal was extremely ambitious: the entire Venetian fleet in the sea between 1544 and 1602 consisted of 117 to 135 light galleys and 6 to 18 great galleys. Thus the Arsenal was keeping on its premises a reserve nearly equal to the state's entire fleet, which would pose considerable organizational and calculational problems for its management.

Examination of materials and components constituted another regular matter of concern, and, again, this issue was addressed through the lens of the 100-galley target. In particular, the reports raised concerns about the quality of wood and its subsequent storage on the Arsenal's premises. Analysis of labour consisted of a quantitative description of manpower along with comments on the quality of the workforce, especially workers and people at intermediate levels in the organization. In general, the reports expressed concern about finding enough good workers to meet the increasing production demand and properly manage raw materials. Finally, the official reports address what Zan (2004b) calls broader organizational issues: contracting in and out, discipline of the workforce, and production scheduling.

In contrast to those of the elective officers, the reports by Baldissera Drachio ${ }^{3}$ and Bartolomeo Tadini, experts on the Arsenal, illustrate discursive changes (Zan, 2004b). Drachio and Tadini provided an integrative view of organizational and production processes. In his report of 1586, Drachio discussed the organization of production and logistics, the organization of labour, and the overall organizational structure of the Arsenal. He addressed the recurrent problem of the supply of oak and exhaustion of the forests surrounding Venice by making proposals for improving the conservation of wood at the Arsenal and its use at every stage of the production process. Similarly, he argued that a new standard ship design could standardize work to ensure a more reliable product. As far as the organization of labour was concerned, Drachio recommended motivating the workforce by standardizing the work of gangs and specializing them according to the type of ship, member seniority, and support activities. He also discussed the more cost-effective use of labour and recommended measures to enforce discipline and coordination of work. Finally, Drachio considered the organizational structure of the Arsenal, which he thought should be led by a supertintending executive with the power "to regulate, order, and reform the Arsenal, having authority and absolute power to remove, imprison or ban workers for a period, or for life" (see Zan, 2004b: 158).

Tadini wrote reports in 1593 and 1594 (see Zan, 2004b). Concerning materials, he addressed theft prevention and the reduction of material waste. As for the workforce, he argued that poor productivity stemmed from unreliable attendance, which rendered scheduling difficult. To enable standardization, Tadini made a forecast of the labourcost structure at the Arsenal and proposed this to be conducted on a period basis.

\footnotetext{
${ }^{3}$ Drachio is a largely unknown character. Tadini was the accountant of the Arsenal (see Zan, 2004b).
} 
According to Zan, however, the most innovative aspect of Tadini's reports concerns the involvement of work gang bosses and clerks in the planning and control processes "to foster ... internal competition" (p.160). He suggested a six-month reporting period along with the enforcement of a scheme of rewards and punishment, the latter ranging from public shame up to removal of the gang boss from his position. Further, he supported a weekly breakdown of the six-month reporting period, so that every Saturday the accountant would meet with the supervisors to make forecasts and plan targets for the following week.

In general, the studies on accounting and managerial practice at the Venice Arsenal show how accounting innovations fostered management discourses (e.g., Drachio and Tadini). These discourses-and this is a recurrent theme with respect to state-owned monopolies-do not include any notion of profit maximization but, as Zan (2004b: 165-166) notes, feature "a logic of common good, or public interest both in military and economic terms, inside an organization which cannot even be characterized as profit-seeking, but rather as a public body not operating on the market". For example, the emphasis on materials consumption and waste reflected a preoccupation with proper management of the Arsenal rather than "efficiency" searches driven by a profit-seeking mentality. In this context, control measures over the labour force were subordinated to such purposes.

\section{Cost and Management Accounting Practices between the Renaissance and the Industrial Revolution}

Mercantilism and the State's Intervention in the Economy

Between 1630 and 1720, France underwent a period of economic recession now known as the longue durée. The stagnation of the country over such a long period provided a basis for the ideas of the mercantilists. Mercantilism stressed five factors: the key role of precious metals in a nation's economy, which implied that countries lacking them should emphasize international trade in order to gain access to precious metals; industrialization, especially in textile manufacturing; thorough regulation of economic activity; the deployment of supervisory bodies to ensure the actual enforcement of regulations; and protectionism against foreign imports as a means of promoting domestic industries. The ideas of mercantilism are exemplified in the policies of Colbert, a Superintendent of Commerce and Comptroller of Finances in France, who enacted règlements that covered nearly every aspect of economic life. In the case of the textile industry, the règlements were aimed at ensuring product quality by categorizing dyers and by establishing six stages in the manufacturing process-a system that remained in use until the French Revolution (Herckscher, 1955). In order to foster economic reconstruction in a country characterized by limited social mobility and a lavish lifestyle among the wealthy, the state enforced a policy of royal manufactories, granting privileges to firms operating in sectors regarded as crucial to expand the industrialization project-for example, in 1665, to the Manufacture Royale des Glaces de Miroirs (MRGM, now known as Saint Gobain; see Bhimani, 1994a).

In Spain, the death of the last monarch of the Hapsburg dynasty in 1700 brought the throne to the French Bourbons. The mercantilist ideas current in the Bourbons' home country were particularly suitable for the Spanish setting, where just one-eighth of goods exported to the Spanish colonies in Latin America had been made in the country 
(Herr, 1958). In Spain the implementation of mercantilism created a vast network of royal factories that, unlike those in France, often were state owned (e.g., the Royal Textile Factory of Guadalajara). Importantly, the fortunes of the Spanish royal factories were uneven; firms operating under strict monopolistic conditions (e.g., the Royal Tobacco Factory of Seville) were relatively successful, but those operating under certain market conditions sometimes went bankrupt (e.g., the Royal Textile Factory of Ezcaray).

\section{$\underline{\text { Royal Privileges, Royal Manufactories, and Cost Calculations }}$}

The case of France's MRGM constitutes an early illustration of the policy of mercantilism. As Bhimani (1994a: 402) explains, the state granted the company, which was owned by private shareholders, a twenty-year exclusive privilege to "make mirrors and other crystal objects ... for decorating royal houses and for the public to enjoy". Intending to deter the import of such goods from Venice, which enjoyed the international monopoly of mirror making, the French government made provisions to attract mirror makers from Venice. MRGM underwent some substantial changes, including its amalgamation with Manufacture des Glaces de France (MGF) in 1695, as well as a number of financial problems that arose during the crisis that followed the Spanish war of succession in 1702. As a result, shareholders banned future borrowing and demanded exclusive reliance on MGF's own resources. As far as accounting was concerned, Bhimani (1994a) found that MGF reflected the rationale of order that characterized the first half of the eighteenth century, and that its shareholders enjoyed social prestige inasmuch as the company was operational, profitable, and liquid. As far as accounting was concerned, the firm used a charge and discharge system from its establishment in 1665 until circa 1820 (Lemarchand, 1994; Boyns et al., 1997b: 408409), and that aimed at "stewardship and safekeeping of the firm's resources" (Bhimani, 1994a: 414).

In Spain, the accession of the Bourbons brought more state intervention in the economy. As Helguera (1996: 115) explains, the Bourbons found an economy that looked like "a complete desert ... the consequence of the deindustrialization undergone by the country during a crisis that lasted the whole seventeenth century". During the eighteenth century, the state relied largely upon the notion of royal factories owned and managed by the state to ensure implementation of mercantilist ideas. The Royal Textile Mill of Guadalajara (RTM) was an early example of a royal manufactory that was launched in order to lessen Spain's dependence on other countries in such a pioneer industry as textile manufacturing (Carmona and Gómez, 2002). Other royal manufactories in this industry were located in Almagro, Ávila, Cuenca, Ezcaray, San Fernando, Segovia, and Vallejo. A shortage of qualified workers motivated the state to hire foreign technicians to run operations. In the case of the RTM, some 80 Dutch families were brought to Guadalajara to run production and to teach Spanish apprentices the specifics of textile manufacturing. The foreign masters earned fixed, high salaries that imposed a considerable burden on the firm (Carmona and Gómez, 2002: 234). This transfer of knowledge was organized around the guild structure that still operated in the textile industry in Spain and that aimed at protecting the interests of Spanish operators. In such context, the pay imbalance between Dutch and Spanish workers provoked some organizational problems. 
In contrast to other Spanish royal manufactories that operated under monopolistic conditions for reasons fiscal (e.g., tobacco) or strategic (e.g., gunpowder), the textile industry had to face competition from well-established foreign firms. From their inception, the royal textile manufactories in Spain reported financial losses (on Ezcaray, see Prieto-Moreno and Larrinaga-González, 2001; on Guadalajara, see Carmona and Gómez, 2002).

The manufacturing process at the RTM was governed by instructions that encompassed every aspect of the production process, which combined what present-day terminology would call mass production with stages characterized by craft technology. The organization of production around separable stages facilitated cost calculations. For the RTM, the archives show a considerable amount of cost data, although there is no trace of regular periodic calculation (Carmona and Gómez, 2002: 243). In particular, Carmona and Gómez reported that the RTM implemented standards to control the activities of both management and workforce and, for the latter, differentiated between Dutch and Spanish workers. The use of such calculations is shown by reports dated 1741 and 1742 and aimed at providing an objective basis for salary and wage costs. In 1742 , the salaries of support departments were apportioned to production cost on a oneeighth basis to the cost of a yard of white twill. Such reports reveal a gradual evolution from guild control at the beginning of the century to formal cost control around the 1740s. In contrast to the predictions of Fleischman et al. (1995), who argued that standards for labour required more sophistication and therefore would be adopted later than those for raw materials, Carmona and Gómez (2002) found standards of control over labour in the absence of similar calculations for raw materials.

The Royal Textile Factory of Ezcaray illustrates another case of a royal manufactory operating in a competitive environment (Prieto-Moreno and LarrinagaGonzález, 2001). Like the RTM, the Ezcaray manufactory eventually filed for bankruptcy. For their observation period, 1767-1785, Prieto-Moreno and LarrinagaGonzález demonstrated that the firm deployed considerable cost calculations, a finding that supports arguments made by Carmona and Gómez (2002) concerning early cost systems in competitive markets. First, the Ezcaray manufactory enforced cost calculation that had an ad hoc rather than a periodical character (Prieto-Moreno and Larrinaga González, 2001). Such calculations were performed by the accountant and two assistants, and included budgets and the use of cost data for pricing purposes. The high profile of the accountant in the management of the Ezcaray manufactory echoes a long tradition in the Spanish public sector (e.g., in the construction of the monastery of El Escorial at the turn of the sixteenth century; see Zarco Cuevas, 1990). Second, Prieto-Moreno and Larrinaga González found no trace of integration between costing calculations and accounting data kept for external purposes-perhaps owing to the use of a single-entry bookkeeping method and, in the main, to the nonperiodic character of cost calculations. Finally, the management at the Ezcaray factory relied on cost calculations to support its claims for funding from shareholders as well as to get state subsidies from the Crown (see Prieto-Moreno and Larrinaga-González, 2001).

The RTF is regarded as the canonical case of management within the Spanish system of royal factories (Alvarez et al., 2002). This manufactory started operations in the late seventeenth century in Seville, the city having been given the tobacco production monopoly as compensation when Cadiz received the monopoly of trade with the Spanish colonies in Latin America. At that time, the RTF made snuff (its main 
product up to the mid-eighteenth century) and cigars. As the demand for tobacco products increased, the supervisory body of the RTF decided to move the factory premises to a purpose-built building outside the city walls. Operations began in these new premises in 1758, at which time the RTF employed 1,400 operators and contributed $28 \%$ of total Crown income (Artola, 1982). Following the spirit of the mercantilists, operations at the RTF were regulated by instructions issued by its supervisory body in Madrid. The regulations were highly detailed and comprehensive, covering matters such as the stages of snuff production, prevention of theft, accounting procedures, and measures to ensure product quality.

The RTF has attracted the interest of a number of accounting scholars (e.g., Gutiérrez Hidalgo, 1993; Carmona et al., 1997, 2002; Romero Fúnez, 1997; Gutiérrez Hidalgo and Romero Fúnez, 2001a, b; Álvarez et al., 2002; Romero Fúnez, 2005). Carmona et al. (1997) drew on the Foucauldian framework of power/knowledge to examine the functioning of cost accounting practices at the RTF (Foucault, 1977). From this perspective, accounting practices are part of a disciplinary system that instills selfsurveillance and auto-regulation of organizational activities. Accounting constitutes a form of power/knowledge comprising regimes of calculation and associated discursive practices that operate as a scheme of surveillance. Such an approach, which had already been used by certain accounting scholars (e.g., Hoskin and Macve, 1986; Miller and O'Leary, 1987), had rarely addressed the disciplinary power of accounting in actual factories.

In 1773, the regulatory body of the RTF issued an instruction aimed at implementing cost accounting practices. Carmona et al. (1997) used this document, along with the regulations issued from 1744 through 1790 and the archival evidence on the actual practice of accounting at the RTF, to show how accounting mediated disciplinary practices for raw materials. The tobacco leaves were extremely expensive and there was high risk of theft and smuggling. To deter such malpractices, the RTF applied extensive accounting controls to the flow of tobacco as it passed from one production stage to the next, and established standards for production waste to minimize spillages, breakages, and "unnecessary" loss of materials during transportation within the factory and during the manufacturing process. Such accounting controls were reinforced by physical controls over operators and middle managers, for example, searching them as they left the factory. In general, Carmona et al. (1997: 413) found that the emergence of cost accounting practices in the RTF as a disciplinary regime was intertwined with the state's recognition of the importance of tobacco as a source of revenue, but also with the status accorded to the RTF as a symbol of the might of the Spanish Crown. The implementation of accounting-based controls for direct labour and direct materials was particularly intense for those phases of the production process that were not susceptible to effective visual supervision and, hence, provided opportunities for theft and smuggling.

The case of the RTF also illustrates the relationship between accounting and spatial practices in the factory (Carmona et al., 2002). When the RTF moved into a purpose-built building outside the city walls, the intervention of detailed accounting calculations into factory space resulted in calculable spaces and a method for governing individuals. In particular, the system of cost centres enforced by the cost instruction of 1773 reconfigured factory spaces and enabled a system of discipline over areas and individuals with below-standard performance. 
During the eighteenth century, Spain ruled many Latin American territories. The case of the gunpowder monopoly in New Spain (present-day Mexico) illustrates the extent to which cost accounting calculations across state-owned enterprises may have constituted a general phenomenon (Núñez Torrado, 2002 a, b). Gunpowder was of course a crucial military resource, and it also served an important function in mining, providing the country with the precious metals that the mercantilists deemed essential. Indications of mismanagement by those in charge of renting out this critical monopoly led the state to take over the production of gunpowder in New Spain from 1766 (Núñez Torrado, 2002b: 281). This measure was enforced by José de Gálvez, a General Inspector of New Spain, who was instructed to maximize the income from the Crown monopolies and the collection of existing taxes. In 1777, Gálvez enacted an ordinance to regulate the production of gunpowder in New Spain. The ordinance covered the organization of production, the role of the accountant, and the nature of the production process for gunpowder-which differed according to its use either in mining or in the military. Overall, the findings of Núñez Torrado $(2002 \mathrm{a}, \mathrm{b})$ indicate that the gunpowder monopoly differed from the textile (e.g., RTM) and tobacco (e.g., RTF) industries in its use of accounting calculations for management purposes. Whereas the RTF used cost calculations to enforce discipline and surveillance on the shop floor, and the RTM used them to differentiate individuals and enforce piece-rate systems, accounting controls in the gunpowder monopoly in New Spain were primarily aimed at tracking the flow of sensitive materials across the various stages of the production process.

The historical research into cost and management practices of Portuguese companies is still sparse. The study of Matos-Carvalho et al. (2004) on the Silk Factory Company in the eighteenth century constitutes a significant exception. This paper examines the company's methods of product costing, pricing, inventory accounting, expense recognition, and production control in the context of the political, economic, and social settings of eighteenth-century Portugal. Interestingly for our purposes, Matos-Carvalho et al. found that cost and financial records were integrated at the Silk Factory. Furthermore, a main purpose of cost data was the calculation of a cost "price", consisting of direct costs and an apportion of indirect costs. This, the authors argue, enabled managers to compute the full cost of each order and, ultimately, informed decisions on price setting.

\section{Competitive Markets and Crisis in the Nineteenth Century}

\section{The Wider Contexts of Cost Calculation}

During the late eighteenth century in France, there was a steady tendency towards deregulation, market competition, and less intervention of the state in the economy (Bhimani, 1994a: 415-422). French philosophes like Diderot, Montesquieu, and Rousseau had severely criticized mercantilism and its support of ancien régime privileges, but the implementation of their ideas had to await the end of the Napoleonic Wars in 1815 and the triumph of liberalism and market competition in France during the rest of the nineteenth century.

In Spain, in contrast, the end of the Napoleonic Wars resulted in the enthronment of King Fernando VII as an absolute monarch and heralded a return to the institutions of the ancien régime, including extensive witch hunts for anyone with liberal ideas and the 
restitution of the Inquisition on 13 May 1814. The ideas of absolutism "pervaded every aspect of economic life", and the Catholic Church, "the genuine depositary of the purest essences of absolutism" (Cuenca Toribio, 1976: 115, 116), regained its political and social influence. This ideological catastrophe for the liberals coincided with an economic crisis caused by the loss of Spain's colonies in Latin America, and resulted in the succession of three finance ministers in 1817-1818. Throughout this politically turbulent century, Spain witnessed the continual alternation of liberals and conservatives in government, and such political turmoil tended to prevent the creation of industrial infrastructures in the country.

\section{Industrial Accounting in Nineteenth-Century France}

Historical research into the management accounting practices of French firms during the nineteenth century has focused on the implementation of industrial accounting (see Boyns et al., 1997a,b). Industrial accounting-incorporating cost calculation into an accounting system based on double entry bookkeeping-was developed by industrial enterprises for managerial purposes (Boyns et al., 1997a: 17) and has been linked by some commentators to the increasingly competitive markets that were experienced by France after the abolition of royal privileges (Nikitin, 1990: 78; 1996a: 94). There is general agreeement with Nikitin's finding that industrial accounting had begun by 1820 (Boyns et al., 1997a: 161).

MGF, a relatively early adopter of industrial accounting (Nikitin, 1990; Bhimani, 1994a), had four branches: its headquarters in Paris, mirror factories in SaintGobain and Chauny, and a soda factory in Chauny. Nikitin (1990) found that in accounting for glass production, the company distinguished between the three stages of the manufacturing process: pouring, abrasion, and polishing. This distinction resulted in sets of unitary costs for every stage of the manufacturing process (Nikitin, 1990, p. 79), which led to an overall example of process costing. In October 1832, the new doubleentry bookkeeping system was fully implemented, along with its accompanying series of rules.

From the firm's perspective, the cost of each branch included all its expenses for raw material, wages, and maintenance and repair, as well as all its investments, including the construction of buildings. Nikitin (1990: 81) explains that the manufacturing cost determined the "price" at which the branches sold their production to the Paris headquarters, the only division of the company that could sell directly to customers. Thus a new cost price was calculated in Paris, including operating costs, depreciation, and dividends.

In his detailed account of industrial accounting at Saint-Gobain, Nikitin (1990) focused on five issues:

a) direct and indirect costs. In the case of labour costs, indirect costs consisted of administrative expenses that formed part of the overhead.

b) production costs and cost per unit. It was clear to the Board of Directors of Saint-Gobain that the rate of absorption of overheads was driven by production levels.

c) continuity of accounting methods. These methods enhanced the comparability of data over time. 
d) motivation of employees. By 1833, Saint-Gobain had implemented a remuneration system that was scientifically based and its outcomes determined the amount of bonuses. In general, the variable portion of employees' salaries ranged between $20 \%$ and $30 \%$. This relatively large variable wage component reflected management's initial distrust of operators.

e) depreciation. Depreciation did not change during the eighteenth century, when it consisted of charges according to the actual value of buildings, machinery, and inventories. However, by 1872, the directors realized that the firm required heavy investment in machinery in order to deter competition. Consequently, the firm began to distinguish between ordinary depreciation "calculated according to steady rules" and extraordinary depreciation "determined by the Board of Directors according to the profit and rectifying the slow progress of the ordinary depreciation as regards the value of some items" (Nikitin, 1990: 90).

Overall, Bhimani's (1994a: 433) examination of accounting changes at Saint-Gobain led him to conclude that they reflected more than mere technical and procedural methods applied in a void and isolated from broader social, economic, and politicocultural forces.

The French case of Decazeville exemplifies industrial accounting in one of the leading sectors of the Industrial Revolution: ironworks (Nikitin 1996b; Boyns et al., 1997a: 155-161). As far as cost accounting was concerned, Decazeville focused on the calculation of costs for intermediate products, transfer prices, and causes of cost variations. Intermediate products play a crucial role in the production process of iron. In Decazeville, the accounting procedures established that intermediate products would be valued at their direct costs and that no overhead rate would be charged to work-inprogress. The rationale was that finished goods were the products that interfaced with the market (Boyns et al., 1997a: 158). In contrast, the transfer price to be charged for goods exchanged internally became a contentious issue; although the firm stated that such transactions should be treated as if they were taking place between individual establishments, the absence of market prices for the intermediate products resulted in artificial prices that produced meaningless data and required considerable efforts in record keeping (see Nikitin, 1996b; Boyns et al., 1997a: 159). Finally, analyses of cost variations were conducted during 1838 and 1839 to explain how a decrease in production volume was accompanied by increases in labour costs and loan interests. According to Boyns et al. (1997a: 159), the analyses showed that labour costs had increased as a consequence of greater production in smaller batches, and that the higher total interest payments were caused simply by increases in the interest rate. In general, Boyns et al. (1997a) believe that cost accounting data did not play a dominant role in either the management of Decazeville or the disciplining of the workforce.

\section{Industrialization and Cost Accounting Practices in Nineteenth-Century Italy}

Research into cost accounting practices of Italian firms has emerged quite recently (Zan 2004b). Such investigations have focused on the role of cost management in the increasingly competitive environments featured by that country from the second half of the nineteenth century. Antonelli et al. (2002) examined the records of La Magona d'Italia, a firm that operated in the iron, steel, and tinplate industries. La 
Magona implemented a cost accounting system that aimed to calculate production costs for purposes of inventory valuation, price setting, and, in situations of market competition, support for efficiency improvements. Antonelli et al. (2002) found that this system was heavily influenced by the ideas and practices of British firms operating in that sector, and was insulated from the influence of the long tradition of Italian accounting thought.

Antonelli et al. (2005) studied Manifattura Ginori, a pottery manufacturer whose double-entry bookkeeping system both enabled cost calculation and fit the changing needs of the business as it evolved from artisanal manufacturing to large-scale production. Manifattura Ginori used its cost accounting system to standardize repetitive tasks, set piecework wage rates, and establish product prices. The findings of Antonelli et al. (2005) indicate that despite the close links between Sèvres and Ginori during the eighteenth century, the former was an unlikely source of practices for the latter, although "other French manufacturers may have been". In particular, Ginori's cost practices were similar to those of firms like Saint-Gobain, the Baccarat Crystalworks, and the ironworks of Decazeville. In line with results found for La Magona d'Italia, the findings for Ginori indicate that cost practices seem more likely to have inspired accounting texts than vice versa.

\section{$\underline{\text { Cost Calculations in State and Privately Owned Firms in Spain }}$}

The restitution of absolutism and the ideas of mercantilism in Spain after the Napoleonic Wars supported state intervention in the economy and a leading role for royal manufactories. The country experienced a severe economic crisis following the loss of its overseas colonies and accentuated by the of the wealthy to spend their money on luxury goods rather than investing it in manufacturing firms. Again, the wealth of the RTF archives has provided a basis for academics investigating the role of cost calculations in nineteenth-century firms in Spain (Carmona and Macías, 2001; Macías, 2002a, b; Carmona and Gutiérrez, 2005).

Carmona and Gutiérrez (2005) examined the outsourcing of cigarette manufacturing at the RTF during the economic crisis of 1817-1819. The loss of the Spanish colonies diverted colonial remittances and donations from Spanish convents, which then experienced serious financial problems. Meanwhile, the RTF was considering launching a new product-the cigarette-which was expected to be much cheaper than the cigar and therefore to succeed in hard times. After the RTF had used its own operators to conduct several tests to calculate the production cost of cigarettes, management concluded that the product could not be marketed because of the high labour costs of RTF personnel. The product had to be manufactured by male operators because they dominated the RTF workforce and otherwise would create gender conflicts inside the manufactory. However, they earned higher salaries than their female counterparts and this made unfeasible cigarette manufacturing. It then occurred to the regulatory body of the RTF to outsource cigarette production to poor Catholic nuns in Seville. Although the nuns provided an ideal solution, because they constituted a disciplined workforce in an enclosed environment, the royal decree that granted them the cigarette production claimed that the concession was motivated by "the royal compassion". Drawing on the Foucauldian framework of power/knowledge, Carmona and Gutiérrez show that the entire payroll of 14 convents manufacturing cigarettes for the entire Spanish market equalled the salaries of six female operators at the RTF in 
February 1818. Accounting was central to a disciplinary system that included strict quality standards, a time schedule for production delivery, standards for consumption of raw materials, and liability for any damage to the raw materials. Production demands kept the nuns working all day for minimal compensation, and some of the convents withdrew from the manufacture of cigarettes; convents with other sources of income had refused from the beginning to participate in the program. Nevertheless, Carmona and Gutiérrez (2005) suggest that the system was less intrusive than that of the panopticon, with its visual controls over operators (Bentham, 1787).

The role of cost accounting data in the relationship between the RTF and its supervisory body from 1820 to 1887 was examined by Carmona and Macías (2001), who drew on the insights of institutional sociology. By decree, the supervisory body requested that the RTF implement both cost accounting and a budgetary process, both in the organization and in its reporting. The RTF complied with the demands for a budgetary process while ignoring the request for cost calculation. Carmona and Macías attribute the state's decree to (a) the state regulatory body's quest for legitimacy, (b) the agency of senior employees of the state regulatory body, who were trying to retain their jobs and compensation packages on the eve of the industry's privatization, and (c) the agency's interest in instilling a basis for mimetic isomorphism within the monopoly (DiMaggio and Powell, 1983). The RTF's different responses to pressures for reporting budgeting and cost information were explained by (a) the firm's expectations concerning how much attention would be paid to nonconformity in the two cases, (b) the expected impact of institutional rules and norms on organizational goals, and (c) the extent to which the institutional source was consistent in its demands.

In 1887 the state was having trouble balancing the public finances, and management of the Spanish tobacco monopoly was leased to the Bank of Spain, a private firm (Instituto de Estudios Fiscales, 1976), with a consequent change in accounting systems. Drawing on a vast array of primary sources, Macías (2002b) demonstrated that privatization brought about the use of cost data for inventory valuation, decision making, and performance evaluation. In agency theory terms, she found that privatization gave rise to new agency relationships; the contracts regulating such relationships provided new incentives for control and, hence, new demands for accounting information. Cost data began to be used for decision making after privatization, in 1887. Although such information was used to monitor managerial performance, this practice did not become a stated objective until 1891 (Macias, 2002b: 53-54).

The imposing presence of the Spanish state in all spheres of life kept privately owned firms relatively small and unsophisticated, so there are few surviving records of cost management systems. Ruiz Llopis (2005) examined cost accounting practices at Trenor and Company of Valencia from 1838 to 1926. This firm provides an early example of diversification; its activities spanned trading, manufacturing, agriculture, and financial services. The system of cost accounting aimed to support the transfer of products between the factories and the headquarters and was fully integrated into the double-entry bookkeeping system of the firm; hence it constitutes an early example of industrial accounting in Spain (see also Boyns et al., 1997b). In general, the cost accounting system served purposes of inventory valuation and financial reporting (Ruiz Llopis, 2005: Chapter VI). 


\section{The Literature on Cost Accounting during the Nineteenth Century}

During the nineteenth century in the countries on which this chapter is based, France made the primary contribution to the cost accounting literature. Nikitin (1992, quoted in Boyns et al., 1997a: 85) classifies the works of the French authorities into four categories: (a) texts on single-entry bookkeeping; (b) idiosyncratic texts on cost calculations within a double-entry bookkeeping system, which exerted little influence on later authors; (c) texts that were instrumental in establishing the doctrine of industrial accounting; and (d) texts on the development of industrial economics, which, according to Nikitin (1992), constituted an early predecessor of modern management accounting. Given the purposes of this chapter, I focus here on categories $\mathrm{c}$ and $\mathrm{d}$.

The works of Pierre-Antoine Godard-Desmarest constitute a fine contribution to the theorization of industrial accounting (see Nikitin, 1996a). Godard-Desmarest, a former General Inspector of the Army, purchased Baccarat Crystalworks in 1822 and ran the firm until 1839. During this period, the firm implemented an accounting system that provided management with an "effective knowledge of its costs". Some commentators contend that the cost system was so effective and relevant that it gave the firm a competitive edge over its rivals (Boyns et al., 1997a: 153). In 1827, GodardDesmarest published his Traité Géneral et Sommaire de la Comptabilité Commerciale (Treatise on Commercial Accounting), a text based on his experiences in the army and at Baccarat. The innovative system of industrial accounting at Baccarat consisted of a double-entry bookkeeping system that included cost calculations and tracked the production flow at each stage of the manufacturing process.

In contrast to the complex production system actually used at Baccarat, which comprised multiple processes and multiple products, Godard-Desmarest illustrated his book with much simpler examples. As Garner (1954) notes, this book is particularly relevant in the discussion of accounting for inventory. Godard-Desmarest suggested that fluctuations in the valuation of raw materials during the year should be resolved by determining the average cost of such inventory at year end. If monthly statements on the cost of raw materials were necessary, he said, "we must choose some value more or less inaccurate, and make the necessary adjustment at the end of the year" (quoted in Garner, 1954: Chapter 2). As far as work-in-progress was concerned, Godard-Desmarest argued that accountants should calculate costs for each stage of the production process and open accounts for each departmental work in process "to which would be debited the costs transferred from prior departments as well as the new costs incurred in the department (e.g., direct labour, fuel, and depreciation on equipment) (quoted in Garner, 1954). He demonstrated particular concerns about quality, urging that materials be inspected and classified by quantity and quality, and that receipts and issues entered on "registers and notebooks [be] regularly kept, and under the responsibility of tried and tested accounting employees" (quoted in Garner, 1954).

Around the 1860s, publication of the works of Courcelle-Seneuil, Barlet, Heudicourt, Guilbault, and others marked the establishment of the new doctrine of industrial accounting (Boyns et al., 1997a: 92). This new approach, Boyns et al. argue, may be partly attributed to the emergence in France of "industrial (or business) economics", a subject that had entered the curriculum of the Paris School of Commerce. Industrial economics benefited from the information provided by industrial accounting, and this, Nikitin (1992, quoted in Boyns et al., 1997a: 93) argues, exemplifies an increasing interest in the outputs of accounting systems, not merely in their technical 
aspects. The works of Guilbault are particularly relevant among those published by these authorities. According to Garner (1954: Chapter 2), Guilbault's understanding of process costing was well ahead of his time, for instance in the distinction between fixed and variable overhead costs. Drawing on examples gathered from mining, ironmaking, and sugar refining, Guilbault proposed the use of the average-cost method of pricing raw material into production (Garner, 1954). In particular, Guilbault argued that commercial, sales, and administrative expenses should not enter into the calculation of factory product cost.

\section{Homogeneous Sections, Standard Costing, and Budgetary Control until the Second World War}

The literature on cost and management practices in our four focal countries during the twentieth century has been developed mainly in France. The richness of the twentieth-century archival evidence on management accounting thought and practice has attracted both French and international accounting historians.

\section{The Homogeneous Section: The Works of Lieutenant-Colonel Rimailho}

The implementation of standard costing and budgetary control practices in French firms during the twentieth century is indebted to the efforts of a few visionary individuals. For example, the notion of homogeneous sections (sections homogènes) is crucial for proper understanding of cost accounting in twentieth-century France, as it came to underpin the cost accounting section of the first plan comptable. A homogeneous section is a cost centre organized around a main activity to enable the allocation of its costs to products or to other sections. This notion is strongly linked to Lieutenant-Colonel Rimailho (Bouquin, 1995; Lemarchand 1999, 2002), who in 1927 was appointed head of the Commission Generale d'Organisation Scientifique du Travail (CGOST, later renamed Cégos). In that capacity, Rimailho realized that the calculation of full costs by allocating indirect costs via a single overhead rate was considered less and less satisfactory (Lemarchand, 2002). As a contemporary commentator noted,

The old rules (such as the one which consists in applying the same coefficient to direct labour) provide a thoroughly rough approximation, when absorption rates are about 200 percent. This is why industries with complex production tend more and more to divide up their operations so as to constitute homogeneous groupings where all the expenses are charged on to production. The exchanges from one group to another are valued by using internal selling prices. (DGA 05407 611, Lelong, 1921: 16; quoted in Lemarchand, 2002)

Military plants traditionally enforced a system of workshops with specialized teams that led to a rationalization of the production process. Drawing on his military experience, Rimailho proposed the implementation of homogeneous sections "in such a way that different specialized activities which make up the section are, in principle, employed in the same proportions for each task undertaken in the section" (Rimailho, 1928: 66; quoted in Lemarchand 2002). This homogeneity enabled the use of an hourly rate, or any other allocation rate, to apportion overheads to individual orders. In the case of hourly rates, this enabled the calculation of the cost of an order as a function of the time spent in each section. 


\section{$\underline{\text { Scientific Management and Standard Costing }}$}

Early twentieth-century French firms deployed sophisticated cost systems (Bhimani, 1993, 1994b). Of particular relevance for this chapter is the case of Renault, the car manufacturer. The firm was founded by Louis Renault in 1898, and at the outset of the First War World it employed nearly 5,000 people. As Bhimani (1993: 4-5) notes, the war brought about some changes in its production portfolio (the company supplying the army with war vehicles and munitions) and also in its internal accounting procedures. In 1916, the head of finance and accounting at Renault requested an independent assessment of the firm's accounting system. The report suggested that accounting functions should be reorganized into four areas: financial accounting, accounting for material, factory accounting, and cost-price accounting. The new accounting method should conform to "la méthode Taylor" (in reference to Frederick W. Taylor's Shopfloor Management). This notion was not a new one for the car industry (Zimnovitch, 2001), nor it was new to a firm that had, in 1912, submitted a directive entitled "Implementing work rates" to its workshop managers and production executives. According to Bhimani (1994b: 658), the directive detailed how time and motion studies and the rate payable to employees for individual tasks were to be coupled. After the time and motion studies led to work speed-ups, the workers complained that they could not keep pace and that improvements in productivity were not accompanied by salary increases. This conflict resulted in several strikes.

The weak relationship at Renault between productivity and operators' compensation violated one of the basic tenets of scientific management and even prompted Taylor himself to write a letter to a member of Renault's management team (Bhimani, 1993). The standardization of working practices continued at steady pace during the next decade, although Renault established mechanisms to ensure "a calculable link between pay and the will to produce". On 24 January 1928, the General Control Department established the correct method of payment for a particular machine operator (quoted in Bhimani, 1994b: 664-665):

The operator will be paid as follows:

1) He will be paid a predetermined hourly wage rate. The workshop supervisor is responsible for calculating the amount and conveys the information to the wage accountant ...

2) In addition to the hourly wage, operators are also paid a bonus. This bonus rewards the proper execution of tasks, savings obtained on overhead costs, the number of rejects, etc. ...

3) In addition to this bonus, another hourly bonus is paid to recognised seniority ...

4)

Bhimani (1994b: 671) contends that the implementation of such sophisticated cost accounting and control practices cannot be disentangled from the personality of Louis Renault nor from a complex web of mobilizing factors such as the need to rebuild the economy in the aftermath of the First World War, or the deployment of an eight-hour day across the industry. 


\section{Problems with the Implementation of Scientific Management: The Case of} Ansaldo in Italy

Ansaldo, a Genoa-based firm, operated in the interrelated fields of engineering, shipbuilding, and metal and steel manufacture during the second half of the nineteenth century and early decades of the twentieth century (Antonelli et al., 2004). The company experienced considerable growth until the early decades of the twentieth century, when it underwent severe financial problems that eventually resulted in the company's being taken over by the Institute for Industrial Reconstruction (IRI), the state's financial holding unit, in the 1930s. During the period 1903-1921, the firm was owned by the Perrone brothers, who demonstrated interest in scientific management but were not convinced that such methods were suitable in the small batch production that Ansaldo featured. During the market upheaval and financial problems of the postwar years, the Perrone brothers had little time to implement such changes in spite of being persuaded that they would benefit the firm. In the 1920s, an emphasis on efficiency brought about some changes towards a more scientific management approach, but it was not until 1935, when the state took management of the firm, that Ansaldo implemented organizational changes that conformed to prescriptions of scientific management. Importantly, the passing of Ansaldo into state hands catalyzed the adoption of scientific management, though the prevailing organizational structure acted as a barrier to change.

\section{$\underline{\text { Budgetary Control }}$}

In France, the implementation of budgetary control started in the 1930s (Berland, 1997, 1998a; Berland and Chiapello, 2004). Budgetary control consists of comparing activity forecasts (categorized into objectives or standards) with the corresponding achievements; the variance between these two figures is then interpreted as good or bad performance (Berland, 1998b, 2001). Research into the implementation of budgetary control in French firms has relied on the work of Nicolas Berland and focused on case studies (Berland, 1997), diffusion and dissemination patterns (Berland, 1998b), the levels of environmental uncertainty that fostered the implementation of the technique (Berland, 2001, 1998b), and international comparative studies (e.g., Britain and France; see Berland and Boyns, 2002).

Berland found that budgetary control comprised a number of individual practices such as standard costing, whose idea was known in France circa 1920 although there was a forty-year lag until its actual implementation in firms (Zimnovitch, 1997). The new technique diffused through a number of mechanisms such as professional reviews, books, the role of organized groups such as Cégos, some professional organizations (e.g., engineers; see Berland and Boyns, 2002), and the experiences of the public sector (Berland, 1998a b). In spite of such awareness among French firms, few of them implemented the technique; and of those that did, many did not use budgets in every part of the organization. In his examination of dissemination patterns, Berland (2001) found that the factors that conduced to adoption of budgetary control by firms such as the Compagnie d'Electricité de Strasbourg (a monopoly) and Pechiney (a cartel; see Berland and Boyns, 2002: 343) included being able to formulate reliable forecasts and operating in stable environments. In France, the implementation of budgetary 
control was not restricted to large firms that had adopted a decentralized structure (Berland, 1998a).

\section{Conclusions}

The review in this chapter suggests different patterns of historical research in our focal countries of France, Italy, Spain, and Portugal. In France, scholars have focused on the eighteenth through the twentieth centuries. In Italy, accounting historians have studied the evolution of accounting theory, while studies on the history of cost and management accounting have been mostly confined to the emergence of such practices around the turn of the seventeenth century and, recently, to cost accounting practices in nineteenth- and twentiethcentury organizations. In Portugal, where interest in historical matters has been growing, researchers have focused on the emergence of the accounting profession during the eighteenth and nineteenth centuries. Finally, in Spain, research on the history of cost and management accounting practices has focused on the eighteenth and nineteenth centuries, especially in state-owned enterprises. Such diverse patterns of research may be attributed to a variety of factors: the availability of archival sources, actual differences in the development of cost accounting practices in organizations, the interest of accounting scholars in particular periods, and the status of historical research in the community of accounting academics. This, in turn, makes it difficult to compare historical cost management practices across countries.

In general, however, the studies reviewed in this chapter suggest that social and political contexts overwhelmingly influenced cost and management practices in our focal countries. During the Renaissance, the ideas of the CounterReformation and the Scholastics exerted a considerable influence in the focal countries. As Quattrone (2004: 653) points out, some European monarchs found in the Roman Catholic Church a powerful ally in pursuing their absolutist projects. In conjunction with factors such as plagues, this may explain the strong intervention of the state in the economy to guarantee a "just price" through regulated markets. The perceived objectivity of cost calculations invested both the regulator and the owner with legitimacy in the public eye, even though cost data merely constituted a basis for price negotiation. In Italy, at the turn of the seventeenth century, the Republic of Venice owned its Arsenal for strategic and military reasons, but the Arsenal was also economically crucial. Its managers introduced sophisticated discourses that drew upon advanced notions of cost and work-in-progress, but such discourses were ultimately guided by the idea of public service rather than profit maximization (Quattrone, 2004: 649; Zan, 2004b; Zambon and Zan, 2005). This notion is spread throughout the eighteenth-century documents regarding Spain's network of royal factories. Finally, the increasing competition experienced by French organizations after the 1820 s facilitated the emergence of cost accounting practices to enhance productivity. In Spain, conversely, the triumph of absolutism after the Napoleonic Wars halted the liberalization process and considerably hampered the industrialization of the country. Market intervention interacted with a severe economic and political crisis caused by the loss of the overseas colonies to insulate Spain from the ideas of scientific management that characterized the French setting (Bouquin, 1995; Bhimani, 1993, 1994b; Lemarchand, 1999). 
The studies reviewed in this chapter question traditional contentions that double-entry bookkeeping spread from the fifteenth through the eighteenth centuries and that cost calculations have been implemented only since the advent of the British Industrial Revolution but more especially since the end of the eighteenth century. In contrast, this review has demonstrated that sophisticated cost calculations have been deployed in some of the focal countries since the Renaissance. In the case of Spain, for example, such early cost accounting practices existed but were not integrated into the double-entry bookkeeping system until the late nineteenth century (Ruiz Llopis, 2005). In contrast, evidence from the French setting suggests that the advent of competition after the Napoleonic Wars and the intertwining of cost and financial accounting considerably improved cost accounting practices in firms (Nikitin, 1990, 1996a; Boyns et al., 1997a, b).

There are few comparative studies addressing the dissemination of cost accounting practices across the focal countries. ${ }^{4}$ Much could be learned from examining the diverse patterns of cost accounting in comparable settings. In France, for example, where royal privileges were granted to private individuals around the turn of the seventeenth century, studies thus far have found no trace of cost accounting practices until the advent of competition in the country around 1820. Conversely, in Spain there is evidence of sophisticated cost calculations in royal manufactories since the first quarter of the eighteenth century despite their slow pace toward competition.

The studies reviewed in this chapter to some extent question the conventional wisdom stating that standards were applied first to raw materials and only later to the labour force. On the one hand, at the Venice Arsenal management efforts did primarily target raw materials and other forms of inventory (Zan 2004b, Zambon and Zan, 2005). The same pattern is evident in nineteenth-century French organizations and in the textual material of French cost accounting authorities (Garner, 1954; Boyns et al., 1997a, b). But the patterns in Spanish firms differed greatly; the Royal Textile Factory of Guadalajara implemented sophisticated cost controls that enforced discipline over employees though it had no controls at all over materials (Carmona and Gómez, 2002), whereas the RTF simultaneously deployed strict controls over materials and employees (Carmona et al., 1997, 2002). Further research in this area may explain these differences.

Although the focal countries of this chapter witnessed similar contexts over considerable portions of the observation period of this chapter, cross-country comparisons still are not easy, largely owing to different patterns of historical research. For example, while the eighteenth century has been extensively investigated in Spain, Italian academics still have good research opportunities for that period. Much understanding can be gained from comparative research into the cost practices of firms operating in the contexts addressed in this chapter, which differ from those that have been extensively studied in work already published in international journals.

\footnotetext{
${ }^{4}$ This finding contrasts with the wealth of comparative research addressing Britain and France (e.g., Berland and Boyns, 2002; Boyns et al., 1996, 1997a, b), as is noted above.
} 


\section{ACKNOWLEDGEMENTS}

This study is funded by the CICYT (Spain) grants 2001-0657 and 2004-08176C02-01. I would like to thank Lúcia Lima Rodrigues and Yannick Lemarchand for their help with studies addressing the Portuguese and French settings. I am grateful to Trevor Boyns, Dick Edwards, Fernando Gutiérrez, Anthony Hopwood, Carlos Larrinaga, Marta Macías, and Paolo Quattrone, as well as the participants in the 4th Accounting History International Conference (Braga, Portugal), for their many helpful suggestions on earlier drafts of this chapter. 


\section{References}

Alvarez, M.J., Gutiérrez, F. and Romero, D. (2002). Accounting and Quality Control in the Royal Tobacco Factory of Seville, 1744-1790: An Historical Perspective. Accounting, Business and Financial History 12, 253-274.

Álvarez-Dardet, C., Baños, J. and Carrasco F. (2002). Accounting and Control in the Founding of the New Settlements of Sierra Morena and Andalucia, 1767-1772. European Accounting Review 11, 419-439.

Antonelli, V., Boyns, T. and Cerbioni, F. (2005). The Development of Cost Accounting in Europe in the Nineteenth Century: An Early Italian Example. In University of Cardiff Working Paper Series. Cardiff, UK: Cardiff Business School.

Antonelli, V., Boyns, T. and Cerbioni, F. (2004). The Development of Management Accounting in Italy: Ansaldo in the Early Decades of the Twentieth Century. In University of Cardiff Working Paper Series. Cardiff, UK: Cardiff Business School.

Antonelli, V., Cerbioni, F. and Parbonetti, A. (2002). The Rise of Cost Accounting: Evidence from Italy. Accounting, Business and Financial History 12: 461-486.

Aquinas, St. Thomas (1273, 1947), The Summa Theologica (Benzinger Bros. Electronic edition at http://www.ccel.org/a/aquinas/summa/home.html).

Artola, M. (1982). La Hacienda del Antiguo Régimen. Madrid: Alianza Universidad.

Bentham, J. (1787). The Panopticon Writings. London: Verso (published in 1995).

Bergarmin Barbato, M., Collini, P. and Quagli, A. (1996). Management Accounting in Italy: Evolution within Tradition. In Bhimani, A. (ed.). Management Accounting: European Perspectives (pp. 140-163). Oxford: Oxford University Press.

Berland, N. (2001). Environmental Turbulence and the Functions of Budgetary Control. Accounting, Business and Financial History 11, 59-77.

Berland, N. (1998a). Le Contrôle Budgétaire, Outil D'un Environment Routinier: Un Point de Vue Historique. Enterprises et Histoire 20, 67-82.

Berland, N. (1998b), The Availability of Information and the Accumulation of Experience as Motors for the Diffusion of Budgetary Control : the French Experience from the 1920s to the 1960s. Accounting, Business and Financial History 8, 303-329.

Berland, N. (1997). La Naissance Du Contrôle Budgétaire en France (1930-1960) : Rôle des Consultants, Aprentissage Organisationnel et Jeu des Acteurs Chez Pechiney et Saint-Gobain. Comptabilité-Contrôle-Audit 3, 5-22.

Berland, N. and Boyns, T. (2002). The Development of Budgetary Control in France and Britain from the 1920s to the 1960s: A Comparison. European Accounting Review 11, 329-356. 
Berland, N. and Chiapello, É. (2004). Le Rôle des Réformateurs Sociaux dans le Diffusion de Nouvelles Practiques de Gestion: Le Cas Du Contrôle Budgétaire en France (1930-1960). Comptabilité-Contrôle-Audit 10, 133-160.

Bhimani, A. (1994a). Accounting Enlightment in the Age of Reason. The European Accounting Review 3, 399-442.

Bhimani, A. (1994b). Accounting and the Emergence of the 'Economic Man'. Accounting, Organizations and Society 19, 637-674.

Bhimani, A. (1993). Indeterminacy and the Specificity of Accounting Change: Renault 1898-1938. Accounting, Organizations and Society 18, 1-39.

Bisaschi, A. (2003). The Accounting System of the Venerable Society of the Living and the Dead of Parma in Medieval Times. Accounting History 8, 89-111.

Bouquin, H. (1995). Rimailho Revisité. Comptabilité-Contrôle-Audit 1, 5-33.

Boyns, T. and Edwards, J.R. (1996). The Development of Accounting in MidNineteenth Century Britain: A Non-Disciplinary View. Accounting, Auditing and Accountability Journal 9, 40-60.

Boyns, T., Edwards, J.R. and Nikitin, M. (1997a). The Birth of Industrial Accounting in France and Britain. New York: Garland.

Boyns, T., Edwards, J.R. and Nikitin, M. (1997b). The Development of Industrial Accounting in Britain and France Before 1880: A Comparative Study of Accounting Literature and Practice. The European Accounting Review 6, 393-437.

Boyns, T., Edwards, J.R. and Nikitin, M. (1996). Comptabilité et Révolution Industrielle: Une Comparaison Grande-Bretagne/France. Comptabilité, Contrôle, Audit 2, 5-20.

Carmona, E. and Gómez, D. (2002). Early Cost Management Practices, State Ownership and Market Competition: The Case of the Royal Textile Mill of Guadalajara, 1717-1744,. Accounting, Business and Financial History 12, 231-251.

Carmona, S. (2004). Accounting History Research and its Diffusion in an International Context. Accounting History 9, 7-23.

Carmona, S. and Donoso, R. (2004). Cost Accounting in Early Regulated Markets: The Case of the Royal Soap Factory of Seville (1525-1692). Journal of Accounting and Public Policy 23, 129-157.

Carmona, S. and Donoso, R. (1999). Precios, Espíritu de Beneficio y Sistemas de Costes. Revista Española de Financiación y Contabilidad 100, 403-424.

Carmona, S., Ezzamel, M and Gutiérrez, F. (2002). The Relationship Between Accounting and Spatial Practices in the Factory. Accounting, Organizations and Society 27, 239-274. 
Carmona, S., Ezzamel, M and Gutiérrez, F. (1997). Control and Cost Accounting Practices in the Spanish Royal Tobacco Factory. Accounting, Organizations and Society 22, 411-466.

Carmona, S. and Gutiérrez, F. (2005). Outsourcing as Compassion? The Case of the Manufacture of Cigarettes by Poor Catholic Nuns (1817-1819). Critical Perspectives on Accounting 16, 875-903.

Carmona, S. and Macías, M. (2001). Institutional Pressures, Monopolistic Conditions, and the Implementation of Early Cost Management Systems. Abacus 37, 139-165.

Carmona, S. and Macintosh, N. (2002). Earnings, Interest and Usury: A Genealogical Approach. In International Forum on the Future of Management Accounting and Control Systems Research. Kingston: Queen's University.

Cinquini, L. and Marelli, A. (2002). An Italian Forerunner of Modern Cost Allocation Concepts: Lorenzo de Minico and the Logic of the 'Flow of Services'. Accounting, Business and Financial History 12, 95-111.

Cuenca Toribio, J.M. (1976). Historia de Sevilla: Del Antiguo al Nuevo Régimen. Sevilla: Universidad de Sevilla.

De Roover, R. (1967). The Scholastics, Usury, and Foreign Trade. Business History Review XLI, 257-271.

DiMaggio, P.J. and Powell, W.W. (1983). The Iron Cage Revisited: Institutional Isomorphism and Collective Rationality in Organizational Fields. American Sociological Review 48, 147-160.

Edwards, J.R. and Boyns, T. (1992). Industrial Organization and Accounting Innovation: Charcoal Ironmaking in England 1690-1783'. Management Accounting Research 3, 151-169.

Fernández Conde, F. (2004). La España en los Siglos XIII al XV. Transformaciones del Feudalismo Tardío. Nerea: San Sebastián.

Fleischman, R.K., Hoskin, K and Macve, R. (1995). The Boulton \& Watt Case: The Crux of Alternative Approaches to Accounting History? Accounting and Business Research 25, 162-176.

Fleischman, R.K. and Parker, L.D (1997). 'What is the Past is Prologue': Cost Accounting in the British Industrial Revolution 1760-1850'. New York: Garland.

Foucault, M. (1977). Discipline and Punish: The Birth of the Prison. London: Allen Lane.

Garner, S. P. (1954). Evolution of Cost Accounting to 1925. Tuscaloosa: University of Alabama Press. Electronic version at http://accounting.rutgers.edu/raw/aah/. 
Graves, O.F. and Radcliffe, V. (2004). Preface to Special Theme Issue on Accounting and Public Policy: A Historical Perspective. Journal of Accounting and Public Policy $23,81-84$.

Gutiérrez Hidalgo, F. (1993). Distribución Espacial y Cambio Contable: El Caso de la Real Fábrica de Tabacos de Sevilla en el Siglo XVIII. Unpublished doctoral dissertation. University of Seville, Seville.

Gutiérrez Hidalgo, F. and Romero Fúnez, D. (2001a). Antecedentes Históricos de las Prácticas de Control de Gestión: Estudio de un Caso. Revista de Estudios Empresariales 9, 205-224.

Gutiérrez Hidalgo, F. and Romero Fúnez, D. (2001b). La Gestión del Tiempo en el Entorno Productivo: El Caso de la Real Fábrica de Tabacos de Sevilla (1744-1790). Revista Española de Financiación y Contabilidad 109, 641-662.

Gutiérrez, F., Larrinaga, C. and Núñez, M. (2005). Pre-Industrial Revolution Evidence of Cost and Management Accounting in Spain, The Accounting Historians Journal 32, forthcoming.

Helguera, J. (1996). Empresa y Empresarios Manufactureros en la España del Siglo XVIII. In Comín, F. and Martín Aceña, P. (eds.), La Empresa en la Historia de España (pp.48-73). Madrid: Civitas.

Herckscher, E. (1955). Mercantilis. London: George Allen and Unwin.

Herr, R. (1958). The Eighteenth-Century Revolution in Spain. Princeton: Princeton University Press.

Hoskin, K. and Macve, R. (1986). Accounting and the Examination: A Genealogy of Disciplinary Power. Accounting, Organizations and Society 11, 105-136.

Instituto de Estudios Fiscales. (1976). Datos Básicos para la Historia Financiera de España, 1850-1975. Madrid: Ministerio de Hacienda.

Lane, F. (1944). Andrea Barbarigo. Merchant of Venice, 1418-1449. Baltimore: Johns Hopkins University Press.

Lane, F. (1934). Venetian Ships and Shipbuilders of the Renaissance. Baltimore: Johns Hopkins University Press.

Lemarchand, Y. (2002). The Military Origins of the French Management Accounting Model: A Return to the Mechanisms of Accounting Change. Accounting History 7, 2357.

Lemarchand, Y. (1999). The Lieutenant-Colonel Rimailho. Portrait Pluriel Pour un Itinéraire Singulier. Entreprises et Histoire 20, 9-32. 
Lemarchand, Y. (1994). Double-Entry versus Charge and Discharge in Eighteenth Century France. Accounting, Business and Financial History 4, 119-145.

Lemarchand, Y. (1993). Du Déperissement à L'amortissement: Enquête sur L' histoire d'un Concept et de sa Traduction Comptable. Nantes: Ouest Éditions.

Lemarchand Y. and Nikitin , M. (2000). Histoire des systèmes comptables. In Colasse, B. (ed.) Encyclopédie de la Comptabilité, du Contrôle, et de l'Audit (pp.771-780). Paris : Economica.

Lemarchand, Y. and Parker, R.H. (1996). Accounting in France/La Comptabilité in France: Historical Essays/Etudes Historiques. New York: Garland Publishing.

Macías, M. (2002a). Ownership Structure and Accountability: The Case of the Privatization of the Spanish Tobacco Monopoly, 1887-96. Accounting, Business and Financial History 12, 317-345.

Macías, M. (2002b). Privatization and Management Accounting Systems Change: The Case of the $19^{\text {th }}$ Century Spanish Tobacco Monopoly. The Accounting Historians Journal 29, 31-57.

Martínez Guillén, J. (2005). The Bordázar Memorandum: Cost Calculation in Spanish Printing During the $18^{\text {th }}$ Century. The Accounting Historians Journal 32, forthcoming.

Matos-Carvalho, J., Lima-Rodrigues, L. and Craig, R. (2004). The Manufacturing Accounts of th Silk Factory Company in Portugal, 1745-1747. In University of Coimbra Working Paper Series. Coimbra: University of Coimbra.

Meyer, J.W. and Rowan, B. (1977). Institutionalized Organizations: Formal Structure as Myth and Ceremony. American Journal of Sociology 83, 340-363.

Miller, P. and O'Leary, P. (1987). Accounting and the Construction of the Governable Person. Accounting, Organizations and Society 12, 235-265.

Nikitin, M. (1996a). The Birth of Industrial Accounting in France: The Role of PierreAntoine Godard-Desmarest (1767-1850) as Strategist, Industrialist and Accountant at the Baccarat Crystalworks. Accounting, Business and Financial History 6, 93-110.

Nikitin, M. (1996b). Comptabilité et Analyse Financière à Decazeville dans les Années 1830. Entreprises et Histoire 13, 53-65.

Nikitin, M. (1992). La Naissance de la Comptabilité Industrielle en France. Unpublished doctoral dissertation. University of Paris-Dauphine, Paris.

Nikitin, M. (1990). Setting Up an Industrial Accounting System at Saint-Gobain (18201880). The Accounting Historians Journal 17, 73-93.

Núñez Torrado, M. (2002a). Estudios de Costes en la Renta de la Pólvora de Nueva España ante la Implantación de un Nuevo sistema de Gestión (1757-1787). Revista Española de Financiación y Contabilidad XXXI, 47-74. 
Núñez Torrado, M. (2002b). Organizational Change and Accounting: The Gunpowder Monopoly in New Spain, 1757-87. Accounting, Business and Financial History 12, 275-315.

Prieto-Moreno, M.B. and Larrinaga-González, C. (2001). Cost Accounting in Eighteenth Century Spain: the Royal Textile Factory of Ezcaray. Accounting History 6, 59-90.

Quattrone, P. (2004). Accounting for God: Accounting and Accountability Practices in the Society of Jesus (Italy, XVI-XVII centuries). Accounting, Organizations and Society 29: 647-683.

Riccaboni, A., Giovannoni, E., Giorgi, A. and Moscadelli, S. (2006). Accounting and Power: Evidence from the Fourteenth Century. Accounting History 11 (forthcoming).

Rimailho, E. (1928). Etablissement des Prix de Revient. Paris : CGPF-CGOST.

Rodrigues, L.L. and Craig, R. (2004). Mercantilist and English Influences on the Portuguese School of Commerce, 1759-1844. Atlantic Economic Journal 32, 329-345.

Rodrigues, L.L., Gomes, D. and Craig, R. (2004). The Portuguese Schol of Commerce, 1759-1844: A Reflection on the 'Enlightenment'. Accounting History 9, 53-71.

Rodrigues, L.L., Gomes, D. and Craig, R. (2003). Corporatism, Liberalism and the Accounting Profession in Portugal Since 1755. Accounting Historians Journal 30, 95128.

Romero Fúnez, D. (2005). The Interface of Disciplinary Practices and Accounting: The Case of Royal Tobacco Factory of Seville, 1761-1790. Accounting History 10, 71-97.

Romero Fúnez, D. (1997). El Control de Gestión en la Real Fábrica de Tabacos de Sevilla en la Segunda Mitad del Siglo XVIII. Unpublished doctoral dissertation. University of Jaén, Jaén.

Ruiz Llopis, A. (2005). Análisis Histórico-Contable de la Sociedad Trenor y Compañía (1838-1926). Unpublished doctoral dissertation. University of Valencia, Valencia.

Scott, W.R (1995). Institutions and Organizations. Beverly Hills: Sage Publications.

Silva de Serra Faria, A.R. (2005). Accounting History Research in Portugal, 1990-2004: An Empirical Study. In $4^{\text {th }}$ Accounting History International Conference. Braga: University of Minho.

Tyson, T.N. (1998). Mercantilism, Management Accounting or Managerialism? Cost Accounting in Early Nineteenth-Century US Textile Mills. Accounting, Business and Financial History 8, 211-229.

Wren, D.A. (2000). Medieval or Modern? A Scholastic's View of Business Ethics Circa 1430. Journal of Business Ethics 8, 109-119. 
Yamey, B.S. (2000). The 'Particular Gain or Loss Upon Each Article We Deal In': An Aspect of Mercantile Accounting: 1300-1800. Accounting, Business and Financial History 10, 1-12.

Zambon, S. and Zan, L. (2005). Controlling Expenditure, Or the Slow Emergence of Costing at the Venice Arsenal (1586-1633). In Annual Congress of the European Accounting Association. Göteborg: Vid Göteborgs' Universiteit.

Zan, L. (2004a). Writing Accounting and Management History: Insights from Unorthodox Music Historiography. Accounting Historians Journal 31, 171-192.

Zan, L. (2004b). Accounting and Management Discourse in Proto-Industrial Settings: the Venice Arsenal in the Turn of the $16^{\text {th }}$ Century. Accounting and Business Research $32,145-175$.

Zan, L. (1994). Toward a History of Accounting Histories: Perspectives from an Italian Tradition. The European Accounting Review 3, 255-307.

Zarco Cuevas, J. (1990). Documentos para la Historia del Monasterio de San Lorenzo el Real de El Escorial. Cimborrio: San Lorenzo del Escorial.

Zimnovitch, H. (2001) Berliet, The Obstructed Manager: Too Clever, Too Soon? Accounting, Business and Financial History 11, 43-58.

Zimnovitch, H. (1997). Les calculs du prix de revient dans la seconde industrialisation en France. Unpublished thesis, doctorat des sciences de gestion. Poitiers: Poitiers University. 
NOTAS 